\title{
Semantic Interpretation of the Concept “Aqsaqal”in Different Linguistic Cultures
}

Zukhra Ravilevna Agleeva

Lidiia Glebovna Zolotykh

Malika Sagandykovna Kunusova

Olga Vladimirovna Dzhenenko

Gulnara Sidegalievna Umarova

Astrakhan State University, Astrakhan, Russian Federation, West Kazakhstan State University, Kazakhstan

\author{
Doi:10.5901/mjss.2015.v6n5s4p114
}

\begin{abstract}
This article deals with the linguistic unit, which in related linguistic cultures plays a dual role: firstly, in the Turkic languages (Azerbaijani, Bashkir, Kazakh, Tatar, Turkmen, etc.) and in some languages of the Caucasian family, it is the term of the emerged a few centuries ago and rather relevant at the moment concept aqsaqal. Secondly, in Russian and individual Turkic languages, it means an actualized lexical token that can be used both in its primary meaning (Aqsaqal-literally: gray-bearded, with a gray beard, that is old, elderly, wise, intelligent, who has obtained wisdom due to life experience), and in the figurative and ironic meaning (in the sports and political discourses, show business, etc.). Based on an analysis of the functioning of the lexical token in different linguistic cultures and different types of discourse, it is concluded that the old Turkic word aqsaqal not only has survived over centuries, but also has acquired new meanings and thus extended the discourse capacity, reflects the modern Eurasian realities, and is part of the active vocabulary of our contemporaries.
\end{abstract}

Keywords: linguistic culture, aqsaqal, ethno-cultural specificity, semantics, actualization, semantic embodiment.

\section{Introduction}

Ethnocultural specificity of the semantics of the lexical token aqsaqal is determined by its special culturological significance and retains the features of the mentality of a certain ethnic group. The representation of axiological objects of the linguocultural community with the concise word aqsaqal combines the universal and idioetnic reflection of the real world. The use of an integrated approach to the study of the semantics of the word aqsaqal with the involvement of not only linguistic, but also ethnographic, anthropological, psychological, and general cultural data allows providing adequate interpretation of a significant fragment of the cultural space.

Despite the importance and the increased in recent decades frequency of use of the lexical token aqsaqal, there are not so many publications analyzing this concept. Let us review the Russian-language sources.

In the article "Cultural Concepts in the Russian Language of Kazakhstan", E. Zhuravleva called one of the "typical for the Kazakhstani society traditions that determine the mentality of both Kazakhs, and all people living in Kazakhstanthe respect for senior people, especially the elderly," and associates it with the concept aqsaqal. The author refers to the interpretation of the word by V.I. Dahl and gives several examples from modern journalism. The conclusion is made on the decisive nature of this concept, its belonging to the "circle of cultural and historical constants that make up the core of the Kazakhstani mentality" (Zhuravleva).

G.S Umarova in her article "The Concept Aqsaqal as a Reflection of the World Vision of the Kazakhs in the Story by V.I. Dahl "Bikei and Mauliana" noted that the concept aqsaqal in the story "Bikei and Mauliana" reflected the elements of the picture of the being, determined by the features of the activities of representatives of the Kazakh society, enshrined in the national vision of the world, and broadcast by means of the language in communication. The emphasis is made on the fact that the concept aqsaqal in the story by Dahl is used as the concept of practical, that is, everyday philosophy as a result of the interaction of a number of factors, such as national tradition, folklore, feelings, ideology, and the system of values. Describing the aqsaqal's portrait in the story by Dahl, the author concludes that its archetypal attributes are preserved, that reflecting the realities of the Kazakh social life in the nineteenth-century, Russian literature, particularly 
the novel "Bikei and Mauliana" preserved the specific cognitive stereotypes of the Kazakh nation in relation to aqsaqals.

Luiza Samsitova in the abstract of the dissertation of PhD in Philology "Cultural Concepts in the Bashkir Linguistic View of the World," noted that the study of cultural concepts allowed to characterize the mentality, way of life, traditions, customs, philosophy, psychology, and spirituality of the people, reflected in the language. Analyzing the culture of relationship of the Bashkir, the author noted that they "were based on trust and openness. The Bashkirs treat a person of the elder generation with special reverence." The authority of aqsaqals "who play an important role in the formation of personality" is marked, because their wisdom teaches the younger generation "the laws of life, tolerance," teaches to distinguish the good from the evil, etc. (Samsitova, 2014).

The authors of the article "Dictionary of the Eurasian Linguistic Culture" share observations on the "opposite tendencies of development of modern civilization, languages, and cultures." The contradiction pointed out by the authors (globalization as an inevitable demand of the times, on the one hand, and the attempt to preserve one's culture, the language of the people, on the other hand) is typical primarily of multi-ethnic states. Both Kazakhstan referred to in the article and Russia are multinational and multicultural states. The authors pointed to "the specific psychology of peoples ... specific world view inherent in Eurasians" (Sabitova et al., 2011). They present the concept of the "Dictionary of the Eurasian Linguistic Culture"-the description of the dominant concepts of the Kazakhstani national idea. The dictionary entry aqsaqal is provided only for reference. The proposed fragment provides a dictionary interpretation and the encyclopedic, historical, and etymological reference, based on the materials of Dahl's dictionary and the Encyclopedic dictionary, of the concept Aqsaqal in the Eurasian linguistic culture, which includes three points (Aqsaqal-wisdom, knowledge; Aqsaqal-experienced person; Aqsaqal—esteem), which are illustrated by the materials of the Kazakhstani journalism; as well as the data of association experiment. The dictionary article gives an idea of the role of the concept aqsaqal in the national, including linguistic, worldview of the Kazakhs.

\section{Methodology}

The existing scientific studies present the lexical token aqsaqal as etnospecific, inherent in the linguistic culture, about which the authors write. We have decided to show that the general Turkic token is much wider in terms of meanings and functions; it is updated with new semes and connotations. Having become almost international in the Eurasian culture (in Russia, Central Asia, and others countries), it appears in some languages as a cultural concept, in others-as a linguocultural text element (linguocultureme), in the third-as a concept, in other-as a lexical token. The main methods of our consideration of the lexical token aqsaqal were the descriptive, comparative, and distributive methods (which allowed studying the behavior of the compatibility of the lexical token in different meanings, especially in its modern use). The source of the study was the author's catalog compiled based on the texts of fiction, journalism, Internet websites, the Russian National Corpus, recorded fragments of dialogs and polylogs. We decided not to include in this article the results of functioning of the lexical token in the verbal discourse, as these interesting facts are quite voluminous. The material used for the article included the explanatory, etymological, encyclopedic dictionaries, which in one way or another described the lexical token aqsaqal.

\section{Results}

As the survey revealed, aqsaqal as a cultural concept is represented in many linguistic views of the world. The lexical token itself is included in the lexical system of the Russian language, genetically derives from the Turkic languages, in which it means gray-bearded. In the Dahl's "Dictionary of the Live Great Russian Language", we can find the following definition of the word aqsaqal-"in areas bordering Asia and populated by Tatars: an old man, foreman, the elder, elected; it is translated as: grey beard." Obviously, the characteristic of a person of advanced age is based on his appearance.

In the "mental lexicon" (Emmorey and Fromkin, 1989), the same value can be expressed without pointing to the appearance of a person. For example, in the Adyghe languages-the Adyghe and Kabardino-Cherkessian languagesthe concept is expressed with the lexical token nekh"yzh' (literally, 'senior, elder'). And most often, the word nekh"yzh' is followed by the suffixed element $f l$, which derives from the qualitative adjective fly—good: nekh"yzh'yfl. In this context, the suffix element contains the element of respectful attitude to the elders. The lexical token nekh"yzh' or nekh"yzh'yfl occupies an important place in the formation of set expressions, for example: Nekh"yzh'yfl zilem nekh"yshchlefli ileshch [where there is a good elder person, there's a good junior one]; Nekh"yzh'ym zh'e et, nekh"yshchlem g"uegu et [Give the senior the floor to speak, and the junior the way to go]; Nekh"yzh' nemys, nekh"yshchle nasyp [let the senior be honored and the junior be happy]. 
In explanatory dictionaries of Turkic languages, we find historical definitions of the lexical token aqsaqal, which have undergone certain changes, and modern, reflecting the perception of the concept in the national consciousness of various ethnic groups. For example, in the dictionary of the Kazakh literary language, the basic definition of the concept aqsaqal is "an old, respected person." In the Kazakh national worldview, as well as in the mentality of many Turkic and Caucasian peoples, the term aqsaqal and the historically successive categories "respected person," "the governor of the kin," "the elder of the kin" have additional connotative meanings. The semantic embodiment of the word aqsaqal is close to the notion "a person who has life experience and can be a mentor." Such equivalence actualizes the evaluative nature, and this estimate is of pronounced positive nature. The relevant characteristics are given in the Kazakh language and the derivative aqsaqaldi'q: the typical features of a revered person who has seen a lot, has considerable experience; the eldest, respected person, by historically formed traditions - the head of the clan, tribe; the traditional system of parenting. In the Kazakh mentality, the concept aqsaqaldi'q comprised the traditional system of parenting that includes spiritual values, the priority of which for a long period of history was unconditional. Thus, the meaning of the concept aqsaqal includes in the mass consciousness of the Kazakhs extension of the name of the age of a person to the nature of his relationship with people, which always comprises (directly or in the context) the aspect of respect, expression of mentoring with respect to the younger ones, and more often-manifestation of the leadership qualities.

The obsolete meaning of the word aqsaqal (foreman, elder, elected) given in the dictionaries of V.I. Dahl, T.F. Efremova, P.la. Chernykh and in a variety of encyclopedic dictionaries is found in travel diaries and notes, memoirs, etc. The renowned artist V.V. Vereshchagin, who traveled extensively around Asia, noted the features of aul governance in pre-revolutionary Russia: "Upravlenie derevni sosredotochivaetsia v rukakh starshiny i kazy (kaza - dukhovnoe litso, rod sud'i); dolzhnosti eti ne vybornye, a po naznacheniiu i v bol'shinstve sluchaev dazhe nasledstvennye - tak, moi priiatel' Tash, aksakal Khodzhakenta, nasledoval dolzhnost' ot ottsa, kotoryi, v svoiu ochered', poluchil ee ot svoego roditelia i t.d. "; "Pri takom poriadke upravlenie, razumeetsia, chisto patriarkhal'noe: aksakal i kazy, na uslovii vzaimnogo delezha, grabiat narod, i, skol'ko mne ni sluchalos' slyshat', liudei chestnykh v tom smysle, kak my eto slovo ponimaem, nelitsepriiatno, bez vziatok i poborov sudiashchikh i upravliaiushchikh, mezhdu nimi net" [Governance of a village is concentrated in the hands of the elder and the kaza (Kaza-a spiritual person, kind of a judge); these positions are not elected, but assigned, and in most cases even hereditary-thus, my friend Tash Aqsaqal of Khojakent inherited the post from his father, who in turn received it from his parent, etc."; "With this order, the governance is, of course, purely patriarchal: aqsaqal and kazas, on the condition of mutual sharing, rob the people, and I have happened to hear many times from honest people, in the sense as we understand this word, impartially, there is no one judging and governing without bribes and extortion among them] ("From the Journey across Central Asia", 1883). In these contexts, it is certainly spoken not about age or wisdom, experience, but about the administrative position. As you can see, the evaluation of this activity by Vereshchagin is sharply critical. It can be assumed that not all local officials "governed" their subordinates in such a way, but in this sense exactly the token aqsaqal often has a negative connotation, as it characterizes those in power, many of whom even before the revolution had made use of their position and been corrupt. Long before the release of the notes, the artist painted the picture "Uzbek, foreman (aqsaqal) of the village of Hodjakent" (1868), the title of which focuses on the meaning of the word aqsaqal. The sketch helps imagine "foreman of the village"- "thanks to the interaction of various semiotic systems, we have the chance to glimpse into the world of our predecessors" (Agleeva, 2010), see the signs of ethnic mentality in the appearance of the character, and "the total of components of different semiotic systems allows most fully and tangibly representing the depth of concepts" (ibid).

V. Obruchev, the author of science fiction novels "Plutonium" and "Sannikov Land", who participated at the invitation of the Russian Geographical Society in the expedition to Central Asia, wrote the novel "In the Wilds of Central Asia (Notes of a Treasure Hunter)," in which he not only tells about the life of local residents, for example: Aksakal pomog mne naiti provodnika iz mestnykh okhotnikov; aksakal snabdil menia v'iukom khoroshego sena iz liutserny i klevera [Aqsaqal helped me find a guide of the local hunters, aqsaqal gave me a good pack of alfalfa and clover hay], but also provides a brief explanatory dictionary, in which he gives interpretation of the word aqsaqal: "Aqsaqal (Turkic.)-literally: "gray beard", a venerable, respected man, foreman, chief "(ihavebook.org/books/142657/v-debryah-centralnoy-azii.html).

In the works of the Kyrgyz writer Chingiz Aitmatov, different meanings of the analyzed word are presented. In the story "The White Ship," the writer through opposition very concisely conveys what usually distinguishes aqsaqals in his opinion: "Da i naruzhnost' Momuna byla vovse ne aksakal'skaia. Ni stepennosti, ni vazhnosti, ni surovosti. Dobriak on byl, is pervogo vzgliada razgadyvalos' v nem eto neblagodarnoe svoistvo chelovecheskoe" [The appearance of Momun was not of an aqsaqal at all. No staidness, importance, or severity. He was a good man, and at the first glance one could understand this thankless human property in him]. Nevertheless, throughout the work, old Momun is appealed to only as aqsaqal. Compare: 1. Skripia nametennym snegom, prishel'tsy zagremeli podoshvami po verande, zabarabanili v dver'. Aksakal, otkroite! Zamerzaem! [Gritting with the carried snow, newcomers rattled the soles on the porch, knocked at the 
door. - Aqsaqal, open up! We are freezing!]; 2. - Aksakal, ia tebia tak liubliu! Chestnoe slovo, aksakal, kak ottsa rodnogo [Aqsaqal, I love you so much! Honestly, aqsaqal, as my own father]; 3. - Da ne stoit, aksakal, - vozrazil, smutivshis', shofer. - Ty gost', a my zdeshnie, ty sadis' za rul', - ugovoril ego ded Momun [Never mind, aqsaqal, said the embarrassed driver, - You're the guest, and we are local, so you drive, persuaded him old Momun]. This "dissipation of cultural information in the language, which consciously or unconsciously is reproduced by the native speakers," who use the word "in certain situations, with certain intentions, and with a certain emotive modality through a single replica, stimulates semantic embodiment" (Zolotykh, 2013) of the lexical token aqsaqal.

Lev Gumilev wrote: "Ever-changing, dying, and being reborn, as every living creature on our planet, ethnic groups leave a track of the past by committing acts that constitute the skeleton of the ethnic history. This track is the memory of events." The most reliable way to fix the memory of events is the word. Of course, time often brings the new to the semantics of the word, in the scope of its use. For example, in modern Kyrgyzstan, the lexical token aqsaqal operates at the official level ("Famous aqsaqal-academics and professors-appealed to the President as the guarantor of the Constitution, calling him to stop the criminal cases against the opposition members and negotiate with them. It is said in their statement of February 4, 2009" http://www.qwas.ru/kyrgyzstan/ar-namys/izvestnye). The use of the name of the social organization "Council of Aqsaqal" is also rather frequent ("the Council of Aqsaqals of Kyrgyzstan demanded that the US air base was removed from the republic. Aqsaqals declared that the US military presence in Kyrgyzstan threatens the national interests of the republic"-http://www.stoletie.ru/lenta/kirgizskije_aksakaly_trebujut_zakryt_bazu_ssha_ 2010). In recent years, several multiethnic regions of Russia have also started to invite experienced, respected people in the social organizations, which aim to address social issues, issues of interethnic communication. Thus, in the Russian language, the seme "social permanent association, the board of the revered, respected veterans of war and labor" also becomes relevant. Let us refer to the media, covering the process. In the article "Aqsaqals will Bring Peace to our Land," it is reported about the establishment of the Council of Elders in Yugra: "The idea is that it should help solve the "ethnic issue." The bottom line of the advice is simple-many problematic issues of interethnic relations can be resolved in a spirit of respect for elders (http://etnic.ru/about/news/aksakali.html). NTV.Ru spoke about the role that aqsaqals can play in the education of young people: "Although the custom is contrary to Islam, and the ritual itself is a crime according to the Criminal Code, the Ingush youth continues to steal brides. In Ingushetia, the meeting of the elders amended the laws of the mountains, to make them more civilized. Aqsaqals introduced heavy fines for bride kidnappers and approved rates of compensation for the abandonment of blood vengeance" (http://www.ntv.ru/novosti/202086/?fb\#ixzz3gRYpBNuj). In Primorye, "in order to prevent the occurrence of epicenters of extremist and nationalistic disturbances caused by domestic difficulties, linguistic and religious barriers, it is necessary to take urgent steps, <...> including election of leaders from among the elders in the national-cultural autonomies. People will better defer to the opinion of aqsaqals according to representatives of the police and the public. The spiritual leader of the diaspora and the head of the national public organization in tandem can become a source of information for migrants who already are residents and those who are only going to come, and the "Council of Elders" will be able to "extinguish" many flaring conflicts "(http://www.pk25.ru/ news/primorye / 01_09_11). The social activities of such councils are referred to in the following article: "The elders of Nizhnekamsk for over 15 years have been actively involved in the life of the city. And today they have made a very interesting proposal. In the opinion of the aqsaqals, the city urgently needs a funeral agency. Not just an agency, but which would observe all the canons of Islam and Orthodoxy" (http://ntrtv.ru/12275-nizhnekamskie-aksakaly-vstretilis-zachashkoy-chaya-s-merom-goroda.html). As you can see from the last example, the definition aqsaqal is applied to the members of different faiths and ethnic groups, most importantly, they must conform to the representations, which the word assumes: "Est' liudi, kotorym nichto ne daetsia v etoi zhizni prosto. Vsevyshnii, proveriaia ikh na prochnost', prepodnosit im vse novye i novye ispytaniia. Odni lomaiutsia, nakhodia uspokoenie $v$ vine, drugie krepchaiut dukhom. Zhivet on s Bogom $v$ dushe, rabotaet, kak trebuiut tserkovnye kanony, shest' dnei v nedeliu. $V$ voskresen'e otdykhaet, vernee, $v$ etot den' pomogaet drugim. Liudi uvazhaiut ego, nazyvaiut aksakalom Akat" [There are people who do not receive anything easily in this life. The Almighty checking their strength tests them again and again. Some of them break and find solace in wine; others grow stronger in spirit. He lives with the God in his soul, works as the church canons require, six days a week. On Sunday, he rests; or rather, on this day, he helps others. People respect him, calling him aqsaqal Akat] (http://yandex.ru/clck/jsredir?from=yandex.ru).

The Azerbaijani linguistic culture has an interesting semantic interpretation of the concept aqsaqal. The significance of this concept is determined by the creation in 1990 of the Council of Aqsaqals of Azerbaijan, which holds a special place among the civil institutions of the country. For example, the cognitive-discursive analysis of the text of the report of the Extraordinary VI Congress of the Council of Aqsaqals of Azerbaijan allows us to represent the discursivepragmatic activities of aqsaqals in linguistic structures, interpreting high morality. Compare: preservation of national and spiritual values, spread in the society of high human qualities, such as purity and simplicity, formation of morally and 
physically healthy young generation, parenting of the youth in the spirit of fidelity to motherland. The given linguistic categories integrate the results of the diverse experimental and objective activity of aqsaqals.

The expressiveness of words expressing a positive assessment of aqsaqals is superimposed on the emotional and estimating meaning of the epithets and metaphors used with regard to them: the golden fund, valuable people, the cream of society, the most valuable members of the society, etc. Such symbolism brings additional value to the object of the aqsaqal category, not violating directly the "historical content." The system of analogies and assimilation is "the foundation of symbolism in general. Based on it, each thing according to the metaphysical principle $<\ldots>$ explains and expresses this principle in its own way and according to its own level of existence so that all things are interconnected and connected into a single universal harmonic system, which under its many guises is the reflection of its own fundamental unity"(Guénon, 2008). The cognitive stage of meaning-making of the word aqsaqal is the conceptualization of knowledge, in the process of which the semantic completion and peripheral adjustment of the already structured and verbalized concept of education takes place. Proof of this is the story of the traditions of the aqsaqal institution: The Azerbaijani epic "Kitabi Dede Korkut" tells about the institute of aqsaqals, which was a generally respected structure standing on its word and giving advice on all matters of public administration. Dede Korkut was the head of this institute. The word of the aqsaqals of the tribe who followed him was believed the law for people. The wisest aqsaqals of the Azerbaijani society as advisers conducted their activity in the palace of Shah Ismail (http://www.xalqqazeti.com/ru/news/ politics/10500; 18.02.2013/). Consequently, the semantics of the word aqsaqal objectifies in the linguistic consciousness the extralinguistic knowledge as well.

In relation to the Tatar linguistic culture, the attitude to aqsaqals is extremely positive, perhaps because mainly they are associated with the semantic elements wise, experienced, generous, kind and high-minded, old, gray-haired, having gray (white) beard, considering it his duty to pass on his experience, to warn against errors, to do good deeds. Often people turned to aqsaqals for advice, blessing, etc.

We can witness such semantic interpretation of this token in the story by the Kyrgyz writer Ch. Aitmatov "Mother's Field": "Tem vremenem priekhal siuda starik nash odin, vrode by ne po ochen' srochnomu delu. la emu skazala: - Kstati priekhali, aksakal, blagoslovite s dobrym nachalom pakhoty. On razvernul ladoni, sidia na kone, i, poglazhivaia borodu, prosheptal: - Pust' pokrovitel' khleborobov Dyikan-baba pobudet zdes', pust' urozhai budet, kak polovod'e" [In the meantime, our old man came here alone, seemingly about not a very urgent matter. I told him, "You have come just in time, aqsaqal, bless us for a good beginning of the plowing." He unfolded his hands, sitting on a horse and stroking his beard, whispered, "Let the patron of farmers Dyikan Baba visit this place; let the harvest be like a flood]. Quiet, with all the heart, blessing — that is what is characteristic of a true aqsaqal-wise, aware of the life and understanding it, who wants to warn young people against the evil.

Another semantic facet of the word-concept aqsaqal is disclosed in the statement of the editor of the informational and analytical journal "Elite of Tatarstan" A. Khazieva. Describing the modern Tatar literature, she wrote, "Seichas nam ochen' ne khvataet slova "aksakal" v literature. V nashei respublike ran'she byli vesomye imena, k kotorym prislushivalis', kotorykh tsenili - N. Isanbet, G. Bashirov, S. Khakim, A. Eniki, M. Amir, Kh. Tufan, chut' pozzhe G. Akhunov, I. Iuzeev, A. Giliazov - gromkie imena, blagodaria chemu slovo pisatelia slyshali $i$ tsenili raznye sloi obshchestva. ...Oni byli $i$ uchiteliami, i sovetchikami dlia molodykh. Segodnia u nas net takikh velichin, ob"ediniaiushchikh narod $i$ pozvoliaiushchikh literature derzhat' marku. Ochen' talantlivyi, nyne pokoinyi poet $R$. Akhmetzianov odnazhdy zhalovalsia: "vot, mol, ran'she byli kakie aksakaly, seichas takikh net". Deistvitel'no, mesta dlia nastoiashchikh aksakalov $v$ tatarskoi literature poka pustuiut. Vakansiia est', "spetsialistov" net" [Now we are lacking the word aqsaqal in the literature. In our republic, significant names used to exist, whose opinions were respected and valued- N. Isanbet, G. Bashirov, S. Khakim, A. Eniki, M. Amir Kh. Tufan, a bit later-G. Akhunov, I. luzeev, A. Giliazov—dominant names, due to whom the word of the writer was heard and valued by different layers of the society. ...They were both teachers, and counselors for young people. Today, we do not have such figures that unite the people and allow literature to maintain its reputation. The very talented, presently late poet $R$. Akhmetzianov once complained, "There used to be great aqsaqals, not anymore". Indeed, the place for the real aqsaqals in the Tatar literature is empty. There is a vacancy, but there are no "experts"] (http://www.elitat.ru/index. Php? Rubrika).

The different frequent meaning of the word aqsaqal is "an old-timer": 1. ". "Literaturnaia gostinaia", chital'nyi zal biblioteki sobral tsenitelei tatarskoi poezii, gde proshel konkurs chtetsov. Siuda zhe prishli i aksakaly raiona. Oni proveli besedu "Rasskazy starozhilov" [Literary Salon"-the reading room of the library has gathered together connoisseurs of the Tatar poetry, where a contest was held among readers. This event was also attended by the aqsaqals of the district. They had a conversation" "Stories of the old-timers"] (http: // kombibl.wmsite.ru/novosti/den-tatarskoj-kultury); 2. " Mnogo povidavshim $i$ ispytavshim na svoem veku, no ne poteriavshim vkusa $k$ zhizni aksakalam svoei rodnoi derevni posviashchaiu" [I dedicate it to the aqsaqals of my native village who have seen and experienced a lot during their life, 
but have not lost the taste for life] (abstract from the play by T. Minnullina "Almandr of Aldermesh"), etc.

In the artistic discourse, where, according to N.F. Alefirenko, "not only the cognitive and synergetic processing of the eventual, socio-cultural, communicative and pragmatic, and linguistic information takes place, but also its transmutation ..." and "as a result of such linguistically creative transformations of the semantic constituents ... the national vision of the linguistic picture of the world is generated" (Alefirenko, 2009), the general and the specific in the pragmatic use of the polysemant aqsaqal is revealed. In the works of contemporary Russian writers, the lexical token aqsaqal occurs in different meanings and has different connotations, depending on the communication objectives, intentions, and attitudes, i.e. the illocutionary aspect (Austin, 1986). When it comes to customs, way of life, and traditions of Turkic and Caucasian ethnic groups, the first value marked by explanatory dictionaries is often used. For example, in "Ai-Petri" by A. Il'ichevskii, an ambiguous attitude towards aqsaqals is traced. On the one hand, they are the keepers of tradition, strictly guarding morality, a kind of the "morality police," and in this situation, the author uses appropriate vocabulary: "aksakaly vossedali; vremia ot vremeni aksakaly poperemenno pripadali k nemu (stolbu v komnate), provodia sverkhu vniz ladon'iu, shevelia gubami i posle tseluia dokosnuvshuiusia ruku" [aqsaqals solemnly sat; occasionally, the aqsaqals alternately cling to it (the post in the room), stroking it from top to bottom with their palms, moving their lips and after that kissing the touched hand], etc. In the tearoom scene, the attitude to aqsaqals, however, changes, and the author ironically treats them: "Odin aksakal pokhozh na vysokhshego bogatyria. Nad ego golovoi parit oblezlyi belichii treukh. Izredka stariki vspykhivaiut, i togda klekot i rubiashchie zhesty vzletaiut nad ikh stolikom" [One aqsaqal looks like a dried-up hero. Over his head, a shabby squirrel treukh soars. Occasionally, the old men flash and then screams and chopping gestures soar above their table]. The epithet vysokhshii [dried-up] in conjunction with the word bogatyr [hero] is an oxymoron. Violation of lexical compatibility is observed in the second sentence, too. The verb parit' [soar] in the meaning "stay in the air using motionlessly spread wings" is commonly used in the contexts of a different tone (orel parit $v$ nebe [eagle soars in the sky]; gordo parit' [proudly soar], parit' v oblakakh [soar into the clouds], etc.). Oblezlyi treukh parit [shabby treukh soars] is an unusual, obviously decreased, unexpected expression; the use of the definition oblezlyi [shabby] only exacerbates the jest about the elderly. This scene is perceived controversially: on the one hand, the elevated vocabulary, almost philosophical arguments, and on the other-reckless behavior of the characters, which led to a tragedy, described in roughly the same style as the portraits of the aqsaqals: tak galliutsiniruia naiavu, my podvisaem $v$ etoi chainoi; glushim chai; vzletaem ot dvukh glotkov [so, hallucinating in the reality, we hang out in the tearoom; drink tea; take off from two sips], etc.

In the tale by L. Petrushevskaia "Little Fairy," the shop assistant calls aqsaqal the wizard Amati only by the attribute an old man, as evidenced by the references to him (dedulia, dedushka, kak geroi dvenadtsatogo goda [old man, as a hero of 1812]). All other semes present in the lexical token aqsaqal are not implied. The main character of the tale gives the word aqsaqal a negative sense, which is emphasized by the definition bizarre: "Vo aksakal chumovoi! proiznesla prodavshchitsa" [The aqsaqal is totally bizarre!, said the saleswoman]. The main character is one of the young people who are intolerant of the slowness, "retardation" in the perception of the new, which is peculiar to most seniors. The attitude to the old man was also expressed in the characterization by the woman of his words and actions: "... vo dedulia daet, nichego ne tumkaet! ... Vy, dedushka, sluchaino ne s luny rukhnuli?" [... The old man is so strange, doesn't get it at all! ... Do you, old man, live under the rock?].

In "Mysterious Passion," a work about the difficult fate of famous intellectuals of the sixties, Vasily Aksenov uses the word aqsaqal in a sarcastic context. Talking about the Parisian exile, the writer remarked ironically, "K etomu vremeni stala uzhe ponemnogu formirovat'sia sreda novoi "parizhskoi noty". On oglianulsia: ely-paly, dorogie tovarishchi, posmotrite, chto delaetsia - vcherashniaia pustynia napolniaetsia zhizn'iu. Vot idet v molodezhnoi kurtochke aksakal Stalingradskoi bitvy Viktuar Platonov, a iz-za drugogo ugla navstrechu emu vydvigaetsia s trost'iu v zheleznoi ruke glavnyi redaktor zhurnala "Arkhipelag" Vol'demar Emel'ianov..." [By this time, a new medium of the "Parisian music" had gradually become to form. He looked around: Cripes, dear comrades, see what is being done - the yesterday desert is being filled with life. Here in a youth jacket, the aqsaqal of the Battle of Stalingrad Victoire Platonov walks, and from the opposite side Chief Editor of Archipelago Vol'demar Emel'ianov advances towards him with a cane in his iron hand...]. Connection of the phrases $v$ molodezhnoi kurtochke [in a youth jacket] and aksakal Stalingradskoi bitvy [aqsaqal of the Battle of Stalingrad] further emphasizes the writer's attitude to the situation. Aqsaqal means "veteran" here.

Despite the fact that the word aqsaqal was included in the "Explanatory Dictionary of Russian Language" of V.I. Dahl, was widely used in the works by Russian writers of the XIX century (including the story of V.I. Dahl "Bikei and Mauliana" (Umarova, 2013), in the Russian linguistic culture the lexical token is perceived as the name of a "strange" concept, which reflects a different culture. But as a result of "correlation between the history of peoples and the history of cultures" (Gumilev) this token took a significant place in the Russian language.

According to our observations, currently, the formation of the linguocultureme aqsaqal takes place; the lexeme has 
been enriched with new semes; semantic changes, shifts, and displacements are marked while the well-known meanings also persist. Let us consider the primary meaning of the word. Appealing to the token aqsaqal in modern Russian press is rather frequent. This is probably due to the gravity of speech economy (the meaning of the lexical token is well known, it can replace lengthy phrases) or the desire to dilute the concepts aqsaqal and veteran, as the last word is more restricted in the use and has a different stylistic overtone. Mainly in contexts the token functions within the meaning "experienced, having experience in a particular area": "V Ul'ianovskoi oblasti namereny otkryt' "Shkolu glavnogo vracha", chtoby pereobuchat' v nei rukovoditelei meditsinskikh uchrezhdenii. Pomogat' v etom, nadeiutsia v pravitel'stve oblasti, budut "aksakaly", rabotaiushchie glavnymi vrachami uzhe davno. Podderzhkoi i soprovozhdeniem proekta zaimetsia meditsinskaia palata oblasti" [The Ulyanovsk Region plans to open the "Chief Physician School" to retrain heads of medical institutions in it. The government relies on the help of aqsaqals who have been working as chief physicians for a long time. Support and maintenance of the project will be provided by the Medical Chamber of the region] (http://simk.ru/2015/03/03/a-gde-oni-aksakaly/).

Appeal to the experience, knowledge of veterans is typical of other industry sectors, in particular, based on the online article "Aqsaqals will share their experience"-for the economy: "Prezidium oblastnoi Torgovo-promyshlennoi palaty prinial reshenie sozdat' obshchestvennoe formirovanie pri palate, $v$ kotoroe voshli aksakaly oblastnoi ekonomiki umudrennye opytom liudi, kotorye $v$ solidnom vozraste ostalis' neravnodushny $k$ svoemu delu. Nazyvaetsia eto novoe ob"edinenie "Sovet stareishin". V sovet mudreishikh voshli professionaly v svoei otrasli. Tsel' ego sozdaniia - pomoch' segodniashnemu biznesu $v$ reshenii razlichnykh problem. Oni mogut stat' svoeobraznymi nastavnikami, vovremia podskazyvaiushchimi vozmozhnye puti vykhoda iz voznikaiushchikh problem" [The Bureau of the Regional Chamber of Commerce decided to set up community groups in the Chamber, which included the aqsaqals of the regional economythe highly experienced people of a respectable age who have remained indifferent to their business. This new association is called the "Council of Elders." The board of the elders included professionals in their field. The purpose of its establishment is to help today's businesses in solving various issues. They can become a kind of mentors, timely telling the possible ways out of the emerging issues] (http://www.vest-news.ru/article/56933). The lexical token aqsaqal can be found in the announcements of high-ranking officials (often the top figures): covering the official visit of President of Kazakhstan N. Nazarbayev to Uzbekistan and his meeting with the president of this country, the journalist gives information under the heading "Aqsaqals meet again," emphasizing the experience of both politicians and their long stay in power (http://www.uzmetronom.com/2010/03/15/aksakaly_vstrechajutsja_vnov). There are numerous texts like this in the printed media and on the Internet. Their analysis makes it possible to state that most of the texts, in which the polysemant aqsaqal is used to mean "an old, respected person," "an experienced respected person," are characterized by rigor, even officialdom to some extent.

The seme "the eldest" of the lexical token aqsaqal is present in the following context: "Voprosy kak-to pri etom vsplyvaiut o smysle zhizni. Skoree - o rannei smerti. Chto eto za dela - Frants Shubert umer v nepolnykh 32 goda?! Motsart - v 36, Shuman - v 46. Shopen - v 49. Aksakal Chaikovskii - v 53. Eto chto - u vas takie poriadki?" [Somehow, the questions about the meaning of life come up to mind. Rather, about an early death. Is it normal-Franz Schubert died before he was 32? Mozart-36, Schumann-46, Chopin-49. Aqsaqal Tchaikovsky-53. Is that your common rule?]. The lexical token was used to emphasize not the old age of the men of art, but the seniority among the given row of names of famous composers who had had a short life.

In the modern Russian language, there is a tendency of using the word aqsaqal in specific contexts: humorous or ironic (for example, aqsaqal of KVN ("Club of the Funny and Inventive"), aqsaqal of the national team, aqsaqal-car enthusiast, aqsaqal in the law science, aqsaqal of the tennis court, and even aqsaqals of flowerbeds, aqsaqal of family relationships, etc.). The offset of the meaning due to the predominance of the seme "old, honored worker, employee, veteran" is observed in modern journalism. And often the experience is more important, but not the age itself. It is clear that both the defender D. Krasotkin (the chief aqsaqal of our ice hockey), and the singer Vladimir Kipelov (the aqsaqal of Russian hard rock), and a large number of athletes, who had been called veterans and aqsaqals before leaving the big sport had been far from senior age. The article of F. Ermoshin "Rock Aqsaqals on the Summer Porch" gives information about the concert: "24 iiunia bliuzovaia komanda "Udachnoe priobretenie" vmeste $s$ A. Makarevichem vystupili na letnei verande restorana "Dilizhans". Teplaia pogoda, oazis letnei verandy, virtuoznaia igra muzykantov, liubimye melodii - vse eto sdelalo vecher nezabyvaemym. Muzykanty mnogo shutili. Atmosfera byla neprinuzhdennaia, dazhe prazdnichnaia, ved' kollektivu $v$ etom godu ispolniaetsia 40 let. Alekseia "Vait" Belova, lidera gruppy, nedarom nazyvaiut ottsom moskovskogo bliuza. "Aksakal... gorets" - tak otozvalsia o nem "Makar"' [On June 24, the blues band "Lucky Purchase" with A. Makarevich performed on the summer porch of the Diligence Restaurant. Warm weather, an oasis of the summer porch, the virtuoso musicians, and favorite tunes-all this made the evening memorable. Musicians joked a lot. The atmosphere was relaxed, even festive, because the team celebrates 40 years this year. Aleksei "White" Belov, the leader 
of the group, is reasonably called the father of the Moscow blues. "Aksakal ... highlander," said about him "Makar" (25.06.2010; http://www.odintsovo.info/news28651). Aqsaqal in a joking meaning in various years was used in the mass media in relation to the jubilee celebrating L. lakubovich (the aqsaqal of show business), N.N. Drozdov (the aqsaqal of national television). Most frequently, this definition is used by sports journalists, who call aqsaqals the most senior athletes in a team, who are approaching the end of their career (in each sport, it is a different age, although there may be exceptions): "...Khorosho, chto nakanune dusha-chelovek - glavnyi trener, aksakal sbornoi Rossii po pulevoi strel'be O.A. Lapkin potratil chas $v$ gostinichnom nomere na strelkovyi likbez dlia vashego korrespondenta, "chainodauna" strelkovogo sporta" [... It's good that the day before the big-hearted man - the head coach, the aqsaqal of the Russian national team in shooting O.A. Lapkin spent an hour in the hotel room for a small educational program for your correspondent, "chainodaun" of the shooting sport] (Soviet Sport, 2008); "V etom godu dolzhny bit'sia za vykhod v prem'er-ligu, no tol'ko cherez mesiats-dva posle nachala chempionata stanet poniatno, gotova li "Alaniia" $k$ etomu, otmetil aksakal" [This year, they are to struggle for the access to the Premier League, but only a month or two after the start of the championship, it will be clear whether "Alania" is ready for this, said the aqsaqal"] (Sovetskii Sport, 2009); "26 iiulia teper' uzhe aksakal sbornoi, priznannyi master massazha Mikhail Nikolaevich otprazdnoval svoe 55-letie" [On July 26, the then aqsaqal of the national team, a recognized master of massage Mikhail Nikolaevich celebrated his $55^{\text {th }}$ anniversary] (Sovetskii Sport, 2008); "Est' nastoiashchie aksakaly nastol'nogo tennisa, kotorye iavliaiutsia aktivnymi propagandistami nastol'nogo tennisa, zdorovogo obraza zhizni, pokazyvaiut prekrasnyi primer sportivnogo dolgoletiia podrastaiushchemu pokoleniiu. Vozrastnaia kategoriia 65 let $i$ starshe. Aksakaly nastol'nogo tennisa $s$ azartom $i$ iunosheskim zadorom vyiasniali otnosheniia mezhdu soboi" [There are true aqsaqals of table tennis, who are active promoters of table tennis, a healthy way of life, show a perfect example of sports longevity for the younger generation. The age group is 65 years and older. Aqsaqals of table tennis with passion and youthful enthusiasm were sorting out the relationships between them] (Yakutia 24.ru).

In the article about the Russian championship among veterans of biathlon "Aqsaqals of Skis and Rifles," the author also used the transformed phraseological unit, stressing the meaning, in which the token from the title was used: "V techenie neskol'kikh dnei v lesu na levom beregu Volgi, gde baziruetsia sportkompleks UIGU "Zaria" $i$ sozdannyi pri nem biatlonnyi tsentr, prokhodili zabegi streliaiushchikh lyzhnikov. Veteranskie turniry - skoree, ne gonka za medaliami, a vozmozhnost' dokazat' sebe i drugim, chto porokh v porokhovnitsakh eshche est"' [Within a few days in the woods on the left bank of Volga, where the UIGU sports complex "Zaria" is located, as well as the biathlon center affiliated to it, races of shooting skiers took place. Veteran competitions are rather not a race for the medals, but the opportunity to prove themselves and others that there is yet life in the old dog] (Http://ulpressa.ru/2012/03/03/aksakalyi-lyizh-i-vintovki/). In a small excerpt, the paraphrase streliaiushchikh lyzhnikov [shooting skiers], i.e. biathletes, was used.

The playful narrative style is also inherent in Felix Kvadrigin ("On a Kayak"-http://litfile.net/web/95849/9805898693). Speaking in general about serious things, the author gives advice to novice kayakers on behalf of the kayak aqsaqals, i.e. experienced ones who have participated in many difficult swims: "Ob"em snariazheniia, ravnyi odnomu (odnomu!) riukzaku, - velichaishee dostizhenie evoliutsii baidarochnogo turizma. Nachinaiushchemu baidarochniku ne sleduet povtoriat' etot izvilistyi i nelegkii put': ved' sushchestvuiut zhe dlia chego-nibud' baidarochnye aksakaly!"; "... baidarochnye aksakaly rekomenduiut pered nachalom pokhoda prokleit' "shkuru" vdol' ukazannykh mest..."; "Tol'ko prikhodiashchaia so vremenem Vysshaia Baidarochnaia Mudrost' delaet sobliudenie etogo zakona reflektornym. A on vsego-navsego glasit: osmotri stoianku pered ukhodom. Mudrye baidarochnye aksakaly tverdili vam ob etom zakone edva li ne chashche, chem o vsekh ostal'nykh" [The amount of equipment equal to one (one!) backpack is the greatest achievement of the evolution of the kayaking tourism. The novice kayaker should not pass again this tortuous and difficult path: this is what the kayaking aqsaqals exist for!"; "... kayaking aqsaqals recommend before the start of the swim to glue "the skin" along the shown places ..." "Only the higher kayaking wisdom that comes with experience makes the compliance with this law a reflex. It merely reads-examine the encampment before leaving. The wise kayaking aqsaqals repeated this law to you perhaps more often than any other]. Despite the style inherent in the author, in addition to the semes already given in these contexts, he adds extra semes-"craftsman", "professional."

The ironic meaning often is present in the political discourse: "No, sudia po vsemu, eto dobroe nachinanie riskuet prevratit'sia, kak shikarno vyrazhalsia eshche odin politicheskii aksakal Chernomyrdin, v "kak vsegda" [But, apparently, this good initiative risks becoming (as another political aqsaqal Chernomyrdin used to say beautifully) "as usually"] (Komsomolskaya Pravda, 2007); "Aksakal bol'shoi politiki ne bez osnovaniia schitaet, chto Rossiia nedostatochno predstavlena $v$ mezhdunarodnykh sportivnykh organizatsiiakh" [Aqsaqal of the big politics reasonably believes that Russia is not sufficiently represented in international sports organizations] (Trud-7, 2002).

Interestingly, a similar phenomenon is also observed, for example, in the Belarussian journalism (see Article "Aqsaqals" of the Belarussian Music Received Awards from the President of Belarus", which describes the awarding the 
Order of Francysk Skaryna to famous musicians by the President of Belarus Alexander Lukashenko (http://news.tut.by/ politics $/ 70505 . \mathrm{html})$. There is a process typical of many words: the lexical token not very popular in previous years reveals new faces, acquiring new connotations and stylistic coloring. According to A.R. Luriia, "internalizing the meaning of words, we internalize the common human experience, reflecting the objective world with different fullness and depth. "Meaning" is a stable system of generalizations related to the word, which is the same for all people, and this system can only have a different depth, different generalization, different coverage of the subjects designated by it, but it is sure to keep intact the "core"-a certain set of relationships"(Luriia, 1979).

The meaning given in the "Dictionary of Russian Language" of T.F. Efremova has revived-"metaphor: smth. old, long-standing, long used." For example, in the information sketch of A. Kisliakov Aqsaqal is a spaceship-"Vo glavu ugla stavitsia teper' staryi, no ispytannyi vremenem orbital'nyi aksakal - korabl' "Soiuz" [The focus is now made on the old, but time-tested orbital aqsaqal — Soyuz] (http://news.Mail.ru/society). In the same meaning the definition of aqsaqal, is used, for example, by N. Leskova with regard to the Sukhumi Botanical Garden, to describe the "venerable age" of the garden: "Po bogatstvu kollektsii on zanimal odno iz lidiruiushchikh mest sredi dendrariev mira, a po vozrastu eto nastoiashchii aksakal: ofitsial'naia data sozdaniia botanicheskogo sada, "razbitogo lekarem Bagrinovskim v kreposti Sukhum", - 1838 god" [By the wealth of the collection, it held a leading position among the world arboreta and by the age, it is a real aqsaqal: the official date of the creation of the botanical garden, "set up by the physician Bagrinovskii in the Sukhum Fortress" is the year 1838]. In this meaning, the word aqsaqal was also used by T. Ved:

"Na beregu derev'ia-aksakaly, / raskinuv, krony moshchnye zastyli. / V teni ikh priatalis' ustavshie auly - / kogda-to zdes' pereselentsy zhill" [On the bank, the trees-aqsaqals, / having spread their powerful crowns froze. I In their shadow tired villages hid themselves- / once settlers lived here]. (http://proza.kz/ru/prose/out-of-genre/39545.tatyana_ved. derevyaaksakali).

The combination of the two meanings (attributed, on the one hand, to animate, and on the other-to inanimate entities) may be noted in the following context: "I ego iavila nam tysiacheletniaia Kazan', splotivshaia tiurkskuiu $i$ slavianskuiu dukhovnye stikhii. Kazan' iavila istoricheskoe porodnenie etikh stikhii. Etot gorod-poet, gorod-mudrets, gorod-starets, gorod-aksakal vozveshchaet o teploi vselennoi na zemle, a ne o kholodnom kosmose $v$ nebesakh" [And it was shown to us by millennial Kazan that rallied the Turkic and Slavic spiritual verses. Kazan has shown the historical twinning of these two verses. This poet city, sage city, elderly city, aqsaqal city heralds the warm universe on earth, not the cold space in heaven] (http://ww.moskvatatar.ru/news.php).

\section{Conclusion}

An analysis of the content of the concept aqsaqal in the oral discourse, the particularities of the functioning of translation equivalents of the token aqsaqal or descriptive construction, conveying the contents of the non-equivalent to some languages unit-these are just some of the aspects that interest us further, as these questions have not been approached by anyone, it is kind of a gap in intercultural comparisons that requires a description.

Aqsaqal as a cultural concept, a linguocultureme, or a notion is presented in many linguistic views of the world. Through cognitive structures verbalized by the token aqsaqal, the language begins to take a very active part in human cognitive activity. The activity-based approach to the study of the lexical token aqsaqal can reveal its ethnocultural nature.

Thus, the Old Turkic word aqsaqal not only survived over centuries, but expanded its discursive capacity by acquiring new meanings. It reflects the modern Eurasian realities and is contained in the active vocabulary of our contemporaries, promoting cognition of the culture, history, and language of the people living nearby, which "is particularly necessary in these days, when it is important to parent tolerance and respect for other cultures' representatives" (Agleeva, 2006).

This international linguistic unit of general Turkic origin is one of the world models presenters and bears cultural and cognitive information, which contains age-old value paradigms, perceptions, and stereotypes.

\section{References}

Agleev, I.A., \& Alefirenko, N.F. (2014). Regional'naia leksika Astrakhani v "Tolkovom slovare zhivogo velikorusskogo iazyka" V.I. Dalia [Regional lexicon of Astrakhan in the "Explanatory Dictionary of Russian Language" by V.I. Dahl]. Luhansk-Moscow: Publishing House of the V.I. Dahl VSU [in Russian].

Agleeva, Z.R. (2006). Rol' frazeologicheskikh edinits v reprezentatsii natsional'noi iazykovoi kartiny mira [The role of phraseological units in the representation of the national linguistic view of the world]. Sokhranenie i razvitie rodnykh iazykov $v$ usloviiakh mnogonatsional'nogo gosudarstva: problemy i perspektivy - The Preservation and Development of Native Languages in a 
Multinational State: Problems and Prospects: Proceedings of the International Scientific and Practical Conference, in 2 vols, Vol. 2. Zamaletdinova, R.R., Ed., Kazan [in Russian].

Agleeva, Z.R. (2010). Mifologema kak element iazykovoi igry [Mythologeme as an element of the language game] (pp.196). lazyk i kul'tura - Language and Culture: Proceedings of the International Scientific Conference, Belgorod: Publishing house of BSU [in Russian].

Alefirenko, N.F. (2009). Mediadiskurs - modus vivendi na rubezhe KhKh i KhKhl vv. [The media discourse modus vivendi at the turn of the twentieth and twenty-first centuries]. Vestnik Viatskogo gosudarstvennogo gumanitarnogo universiteta: Nauchn. zhurnal Bulletin of the Vyatka State Humanitarian University: Scientific. Journal, Kirov, 1, 3-10 [in Russian].

Asylgaraev, Sh.N., Ganiev, F.A., Zakiev, M.Z., et al. (Eds.) (2007). Tatarsko-russkii slovar' [Tatar-Russian Dictionary]. In 2 volumes. Kazan: Magarif [in Russian].

Austin, J. (1986). Slovo kak deistvie [The word as action]. Novoe v zarubezhnoi lingvistike, Lingvisticheskaia pragmatika - New in Foreign Linguistics, Vol. XVII. Linguistic Pragmatics, 87-108. Moscow: Progress [in Russian].

Chernykh, P.la. (1999). Istoriko-etimologicheskii slovar' sovremennogo russkogo iazyka [Historical and etymological dictionary of the modern Russian language]. In 2 volumes. Moscow: Russkii lazyk [in Russian].

Dahl, V.I. (2002). Tolkovyi slovar' zhivogo velikorusskogo iazyka [Explanatory dictionary of the Russian language]. In 4 volumes. Moscow: Diamant [in Russian].

Efremova, T.F. Tolkovyi slovar' russkogo iazyka [Explanatory dictionary of the Russian language]. Retrieved from: http://www.efremova. info/ [in Russian].

Emmorey, K.D., \& Fromkin V.A. (1989). The mental lexicon. Linguistics: The Cambridge Survey (Vol. III, pp. 124-149). Cambridge (Mass).

Fasmer, M. (2004). Etimologicheskii slovar' russkogo iazyka [Historical and etymological dictionary of the Russian labguage]. In 4 volumes. Moscow: "Product", "Astrel" [in Russian].

Guénon René (2008). Simvolika kresta [Le symbolisme de la croix] (Fadeeva, T.M., \& Stefanov, lu.N., Trans.). Moscow: ProgressTraditsiia [in Russian].

Gumilev, L.N. Ritmy Evrazii: Epokhi i tsivilizatsii [Rhythms of Eurasia: Epochs and Civilizations]. Retrieved from: http://www.bookol.ru/ nauka_obrazovanie/istoriya/207207/fulltext.htm [in Russian].

Luria, A.R. (1979). lazyk i soznanie [Language and consciousness] (pp. 320). Moscow: Publishing House of the Moscow Lomonosov State University [in Russian].

Natsional'nyi korpus russkogo iazyka [Russian National Corpus]. Retrieved from: http://www.ruscorpora.ru/ [in Russian].

Ozhegov, S.I., \& Shvedova, N.Y. (1997). Tolkovyi slovar' russkogo iazyka [Explanatory dictionary of the Russian language]. Moscow: Azbukovnik [in Russian].

Sabitova, Z.K., Zhankidirova, G.T., Skliarenko, K.S., Shantaeva, D.S., \& Shetieva, A.T. Slovar' evraziiskoi lingvokul'tury [Dictionary of Eurasian linguistic culture]. Retrieved from: http://pps.kaznu.kz/2/Main/FileShow2/17797/84/3/7/0/ [in Russian].

Samsitova, L.H. (2014). Kul'turnye kontsepty v bashkirskoi iazykovoi kartine mira [Cultural concepts in the Bashkir language picture of the world] (Doctoral dissertation). Ufa [in Russian].

Studies in the Humanities

Syzdykova, R.K., \& Khusain, K.Sh. (Eds.) (2002). Kazakhsko-russkii slovar' [Kazakh-Russian dictionary]. Almaty [in Russian].

Umarova,G.S. (2013).Kontsept aksakal kak otrazhenie kartiny mira kazakhov v povesti V.I.Dalia "Bikei i Mauliana" [The concept aqsaqal as a reflection of the world view of the Kazakhs in the story by V.I. Dahl "Bikei and Mauliana"] (pp. 22-27). Filologicheskoe nasledie V.I.Dalia - Philological heritage of V.I. Dahl: Proceedings of the Regional Scientific-Practical Conference, Oral [in Kazakhstan].

Zhuravleva, E. Kul'turnye kontsepty v russkom iazyke Kazakhstana [The cultural concepts in the Russian language in Kazakhstan]. Retrieved from: http://refdb.ru/look/2760848-p31.html [in Russian].

Zolotykh, L.G. (2013). K probleme issledovaniia dissipatsii kul'turnoi informatsii v iazyke [To the study of the problem of dissipation of cultural information in the language]. Gumanitarnye issledovaniia - Humanitarian Research, 4, 34-38 [in Russian]. 